\title{
Front Matter: Volume 11524
}

, "Front Matter: Volume 11524," Proc. SPIE 11524, Eighth International Conference on Remote Sensing and Geoinformation of the Environment (RSCy2020), 1152401 (26 August 2020); doi: 10.1117/12.2575653

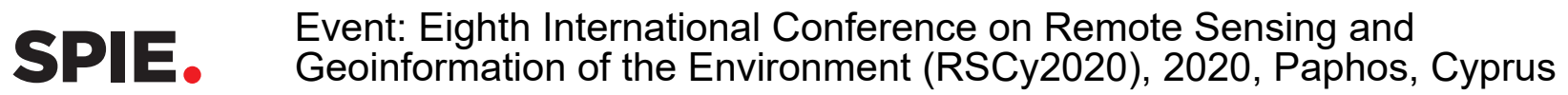




\title{
PROCEEDING S OF SPIE
}

\section{Eighth Intemational Conference on Remote Sensing and Geoinformation of the Environment (RSCy2020)}

\author{
Kyriac os Themistocleous \\ Giorgos Papadavid \\ Silas Michaelides \\ Vincent Ambrosia \\ Diofantos G. Hadjimitsis \\ Editors
}

\section{6-18 March 2020 \\ Paphos, Cyprus}

Guest Editor

Eratosthenes Center of Exc ellence (Cyprus)

Organized by

Cyprus Remote Sensing Society (Cyprus)

In Cooperation with

ESA - (France) NASA (United States) - GEO (Switzerland) - Geman Aerospace Center (Gemany) Department of Electronic Communications of the Deputy Ministry for Research, Innovation a nd Digital Polic y (C yprus) • Copemic us (Belgium) • EIEK (C yprus) - Agric ultural Research Institute (Cyprus) • Department of Meteorology (Cyprus)

\section{Supported by}

Cyprus Forestry Department (Cyprus) - Cyprus Association of Civil Eng ineers (Cyprus) • ICOMOS Cyprus (Cyprus) - Cyprus Tourism Organization (Cyprus) - Eratosthenes Center of Excellence (Cyprus) • EXCELSIOR (Cyprus) • WeObserve (Greece) • Geo University (Greece) • Copemic us Relays (Belgium) - Copemic us Academy (Belgium) - CopHub.AC (Belgium) - FPCUP (Gemany) MedRIN (United States) • Geosystems Hellas (Greece) • CyRIC (Cyprus)

Published by

SPIE

Volume 11524 
The papers in this volume were part of the technical conference cited on the cover and title page. Papers were selected and subject to review by the editors and conference program committee. Some conference presentations may not be available for publication. Additional papers and presentation recordings may be available online in the SPIE Digital Library at SPIEDigitalLibrary.org.

The papers reflect the work and thoughts of the authors and are published herein as submitted. The publisher is not responsible for the validity of the information or for any outcomes resulting from reliance thereon.

Please use the following format to cite material from these proceedings:

Author(s), "Title of Paper," in Eighth International Conference on Remote Sensing and Geoinformation of the Environment (RSCy2020), edited by Kyriacos Themistocleous, Giorgos Papadavid, Silas Michaelides, Vincent Ambrosia, Diofantos G. Hadjimitsis. Proceedings of SPIE Vol. 11524 (SPIE, Bellingham, WA, 2020) Seven-digit Article CID Number.

ISSN: 0277-786X

ISSN: 1996-756X (electronic)

ISBN: 9781510638570

ISBN: 9781510638587 (electronic)

Published by

SPIE

P.O. Box 10, Bellingham, Washington 98227-0010 USA

Telephone +1 3606763290 (Pacific Time) · Fax +1 3606471445

SPIE.org

Copyright (c) 2020, Society of Photo-Optical Instrumentation Engineers.

Copying of material in this book for internal or personal use, or for the internal or personal use of specific clients, beyond the fair use provisions granted by the U.S. Copyright Law is authorized by SPIE subject to payment of copying fees. The Transactional Reporting Service base fee for this volume is $\$ 21.00$ per article (or portion thereof), which should be paid directly to the Copyright Clearance Center (CCC), 222 Rosewood Drive, Danvers, MA 01923. Payment may also be made electronically through CCC Online at copyright.com. Other copying for republication, resale, advertising or promotion, or any form of systematic or multiple reproduction of any material in this book is prohibited except with permission in writing from the publisher. The CCC fee code is 0277 $786 \mathrm{X} / 20 / \$ 21.00$.

Printed in the United States of America by Curran Associates, Inc., under license from SPIE.

Publication of record for individual papers is online in the SPIE Digital Library.

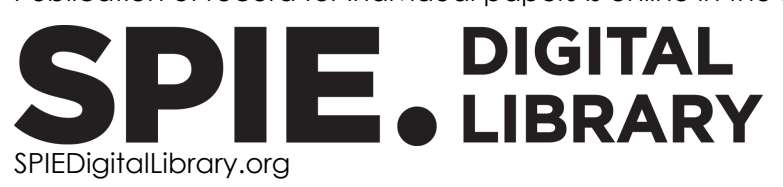

Paper Numbering: Proceedings of SPIE follow an e-First publication model. A unique citation identifier (CID) number is assigned to each article at the time of publication. Utilization of CIDs allows articles to be fully citable as soon as they are published online, and connects the same identifier to all online and print versions of the publication. SPIE uses a seven-digit CID article numbering system structured as follows:

- The first five digits correspond to the SPIE volume number.

- The last two digits indicate publication order within the volume using a Base 36 numbering system employing both numerals and letters. These two-number sets start with 00, 01, 02, 03, 04, 05, 06, 07, 08, 09, OA, OB ... 0Z, followed by 10-1Z, 20-2Z, etc. The CID Number appears on each page of the manuscript. 


\section{Contents}

\section{AGRICULTURE}

1152402 Remote sensing of rice crop areas with UAVs data: Krasnodar region, Russia [11524-11]

1152403 Monitoring maize (Zea Mays L) phenology response to waterdeficit using Sentinel-2 multispectral data [11524-15]

1152404 RECAP: reinforc ing CAP through automated checks and self-assessment [11524-25]

1152405 Remote sensing methods to estimate eva potranspiration incorporating MODIS derived data and applications over Greece: a review [11524-28]

1152406 Spectrometric characteristic s of soils of the subboreal zone of the eastem part of the Russian plain [11524-49]

1152407 A Sentinel based agric ulture monitoring scheme forthe control of the CAP and food security [11524-78]

\section{CULTURALHARTAGE}

1152408 Cloud-to-c loud assessment of UAV and TLS 3D rec onstructions of cultural heritage monuments: the case of Tome Zozzoli [11524-26]

1152409 Study of fluvial processes impact on archaeological sites of the Volga Bulgaria period using remote sensing data [11524-48]

11524 OA The doc umentation of cultural heritage sites in Cyprus using integrated tec hniques: the case study of the Church of Agios Athanasios and Kyrillos [11524-73]

$11524 \mathrm{OB} \quad$ Surveying and mapping of potential sources of pressure in Lefkada tourist areas for sustainable growth and jobs in the blue economy [11524-75]

11524 OC Remote sensing tec hniques fora rc haeology: a state of artanalysis of SAR methods for land movement [11524-79]

11524 OD Stable: structural stability risk assessment [11524-92]

\section{EARIH OBSERVATION}

11524 OE Spectral measurements over test site Novi Iskar for creating a specific data base [11524-17] 
11524 OF Satellite imageny segmentation in lignite mine areas [11524-21]

11524 OG Optical and SAR data for application of Interim Ecological Monitoring (IEM) on Studena Dam, Bulgaria [11524-27]

$11524 \mathrm{OH}$ Easy to use empinical model forgreen vegetation reflection spectrum in VIS-NIR range [11524-36]

11524 ol Digital soil mapping using Sentinel-2 imagery supported by ASTR themal infrared bands [11524-37]

11524 0J Seasonal assessment of the dynamics of sea ice based on aerospace data on Livingston Island, New Shetland Islands in Antarctica and Longyearbyen in the Arctic [11524-38]

11524 OK Convolutional neural networks for detecting challenging cases in cloud masking using Sentinel-2 imagery [11524-53]

11524 OL Ship detection in Cyprus EEZ using Sentinel 1 data [11524-70]

11524 OM Excelsior: Earth observation opportunities for excellence in the Emmena Region [11524-82]

11524 ON An oveniew of electronic comer reflectors and their use in ground deformation monitoring applications [11524-84]

$1152400 \quad$ Preliminary assessment of offshore wind speed around Cyprus based on Sentinel-1 Level 2 OCN data [11524-89]

FORESTS

11524 OP Spatiotemporal changes of forest line and canopy cover between 1945-2019 at selected Greek mountains [11524-16]

$115240 \mathrm{OQ}$ Assessment of forest vegetation state through remote sensing in response to fire impact [11524-31]

11524 OR GIS capabilities in monitoring of forest logging and assessment of bumed areas based on Earth remote sensing data [11524-40]

11524 OS Accuracy validation of digital elevation models for effective forest road management [11524-47]

11524 OT Assessment of post-fire land degradation risk in Lebanon's 2019 fire affected areas using remote sensing and GIS [11524-54]

11524 OU Rational evaluation of forest road network for susta inable development and protection in Greece [11524-56]

$11524 \mathrm{OV}$ Environmental monitoring for consenation and integrated development of a multi-functional Green Infrastructure area [11524-57] 
11524 OW Sustainable development and exploitation of a typical semi mounta inous forestarea in northem Greece [11524-58]

11524 0X Prionitizing forest road upgrade with the use of environmental impact assessment [11524-62]

11524 OY Preliminary spatial analysis for essential forest technical works using digital tenain models [11524-80]

$115240 Z$ Determination of culverts on low-volume roads using G IS and remote sensing [11524-86]

GIS

$1152410 \quad$ Reducing non revenue water in J ordan using GIS [11524-29]

1152411 The Web GIS monitoring and forecasting platforms in the Meditteranean and Black seas [11524-42]

1152412 On-line data access interface for vegetation database at the Tuapkhat massif cliff [11524-43]

1152413 The Black Sea oceanographic web GIS interface new developments [11524-44]

1152414 Use of integration of GIS-based map algebra for land use change [11524-59]

1152415 Timeless land use changes in semi mountainous adjacent area to Athens [11524-74]

1152416 Planning and engagement arenas for renewable energy landscapes, Paros Island example [11524-83]

LAND COVER: URBAN

1152417 Evaluation of urban atlas and street tree layer 2012 local component datasets for Bulga ria [11524-23]

1152418 Architectural evaluation analysis by using GIS: case study Karavas [11524-45]

1152419 Multi-temporal a nalysis of land cover changes using Landsat data through Google Earth Engine platform [11524-69]

11524 1A Mapping and assessment of urban heat island effects in the city of Sofia, Bulgaria through integrated application of remote sensing, unmanned aerial systems (UAS) and GIS [11524-93] 
11524 1B Studying seismic events via satellite interferometry [11524-12]

11524 1C Study of the contemporary state of the landslides in the northem Bulgarian Black Sea coast [11524-14]

11524 1D Rockfalls systematic monitoring using UAVs: the case ofZachlorou village [11524-30]

11524 IE Mapping the Panagopoula landslide extent fitty years afterthe event [11524-33]

11524 IF Permanent infrastructures for continuous space-based monitoring of natural haza rds [11524-65]

$115241 G \quad$ Foods and sea stoms: a nalysis of contemporaneity conditions in Calabria, ltaly [11524-68]

11524 1H Pre-seismic anomalies from satellite data associated with some moderate Vrancea earthquakes [11524-7]

11524 1l Satellite SAR interferometry for monitoring dam deformations: the case of Evinos dam, central Greece [11524-91]

REMOTE SENSING

11524 1] The structure of wind waves and the contribution of its components in the alongshore sandy sediment tansport [11524-1]

$115241 \mathrm{~K}$ Coherent formation and receiving of frequency hopping spread spectrum signals [11524-19]

11524 IL Using of remote sensing data to study transfomation of the Solenoye Lake bay-bar[11524-3]

11524 1M Assess citizen science based land covermaps with remote sensing products: the Ground Truth 2.0 data quality tool [11524-34]

11524 IN Remote sensing as a driving tool for Citizen Science phenology monitoring campaigns [11524-39]

1152410 Remote sensing data fusion algorithm for super-resolution: multi-temporal case [11524-4]

11524 1P Detecting underground structures in vegetation indices: MSR, RDVI, OSAVI, IRG, time series using histograms [11524-5]

11524 1Q Land movement a nalysis from temestrial laser scanner (LDAR) [11524-64]

11524 IR Feature and information extraction for regions of Southeast Europe from Corona satellite images acquired in 1968 [11524-66] 
11524 1S Comparison of potential pollution levels in coastal areas of an lonian island using hierarchical cluster analysis [11524-76]

11524 1T Monitoring of land surface radiative parameters in Buc harest city through themal infrared remote sensing [11524-8]

$115241 \mathrm{U}$ Evaluation of remotely sensed soil moisture products using crowdsourced measurements [11524-88]

11524 IV Assessing climate impacts on urban forest changes using time senies satellite data [11524-9]

UAV

11524 IW Methodological features of aenial survey of coastal relief by UAV [11524-2]

$115241 X \quad$ Use of Earth remote sensing data for the monitoring of the level of soil fertility [11524-41]

$115241 Y \quad$ Verification of UAS photogrammetry approach for mass movement monitoring in alpine tena in: a case study in High Tatras, Slovakia [11524-61]

$115241 Z$ UAV regularmapping focusing on surface mine monitoring [11524-72]

WATER BODIES: COASTAL

1152420 Dynamics of the coastline and topography of Verbenaya Kosa [11524-10]

1152421 Digital bathymetric model of the Burgas Bay, Bulganian Black Sea [11524-51]

1152422 Digital temain model of the Vama and Beloslav Lakes, North Bulgarian Black Sea Coast [11524-52]

1152423 An initial oveniew of tidal and sea level vaniability in Cyprus [11524-60]

1152424 An in situ optical dataset for working towa rds fiduc ial reference measurements based satellite ocean colour validation in the Eastem Meditemanean [11524-63]

1152425 Shoreline changes of pocket beach: a remote sensing application [11524-67]

1152426 UAS-based mapping of depositional landforms along the North Bulgarian Black Sea coast in support of nature conservation [11524-87]

1152427 Estimation of sea level height varia bility in Cyprus using Sentinel-3 satellite altimetry data [11524-90] 
Proc. of SPIE Vol. 11524 1152401-8

\section{Downloaded From: https://www.spiedigitallibrary.org/conference-proceedings-of-spie on 26 Apr 2023
Terms of Use: https://www.spiedigitallibrary.org/terms-of-use}

